Utah State University

DigitalCommons@USU

\title{
Effects of annual burning on grassland in the aspen parkland of east-central Alberta
}

Howard G. Anderson

Arthur W. Bailey

Follow this and additional works at: https://digitalcommons.usu.edu/aspen_bib

Part of the Forest Sciences Commons

\section{Recommended Citation}

Anderson, Howard G. and Bailey, Arthur W., "Effects of annual burning on grassland in the aspen parkland of east-central Alberta" (1980). Aspen Bibliography. Paper 4584.

https://digitalcommons.usu.edu/aspen_bib/4584

This Article is brought to you for free and open access by the Aspen Research at DigitalCommons@USU. It has been accepted for inclusion in Aspen Bibliography by an authorized administrator of DigitalCommons@USU. For more information, please contact

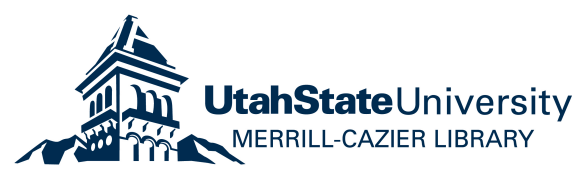




\title{
Effects of anmual burning on grassland in the aspen parkland of east-central Aberta
}

\author{
HOWARD G. ANDERSON' AND ARTHUR W. BALEY \\ Department of Plant Scicnce, University of Aberta, Edmonton. Alta. Canada $76 G 2 H 1$
}

Received June 25.1979

Whats

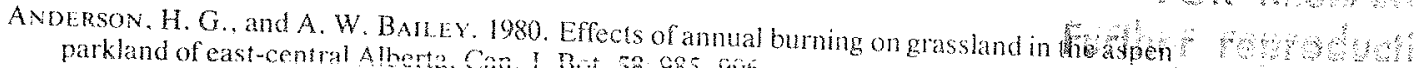
parkland of east-central Alberte. Con. I. Bit. $58,985-9 \% 6$.

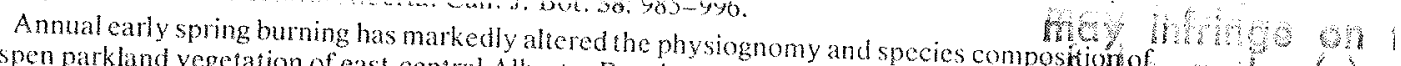

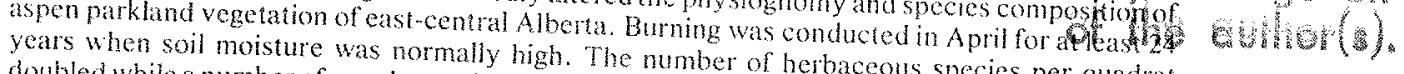
doubled while a mumber of woody specics declined slightiy. Forest cover declined while grassland
increased. In the grass and shrublands, cover of he shrb Symphes cool season grass Festuca scabrella declined of the shrub Symphoricarpos occidentalis and the Carex obusata, C. heliophylla, and Solidugo mis. Major increases in Calamocilfa longifolia, Festuca scabrella and Stipa spartea Solago missourtonsis were noted. While the cover of creased. Cover of all shrubs decreased. Populus tremulecreased; frequency of these species inthe fire adapted Elaeagnus commuiata. Amolus treminloides suckers excepted, while density of tremuloides suckers increased. Burning reduced the ahifolia, Pruntes virginiana, and Populus sedges. Effect of buming on inforescence prod the leaf blade length of all major grasses and herbage production was reduced by burning with the vaned from species to species. Annual about a $50 \%$ reduction. Burning caused an increase in wass and sedge component experiencing the Ah horizon. Buming dis not appear to detrimen organic matter and phosphoms content of horizon.

ANDERSON, H. G. et A. W. BALEY. 1980. Effects of annual burning on grassland in the aspen

parkland of east-central Alberta. Can. J. Bot. 58:985.9\%.

Le brîlage annuel ate début du printemps a alé de caç

composition floristique de la végétation de l'aspen a aléré de façon marquée la physionomie et la a été effectué pendant au moins 24 ans en avrispen parkland au centre-est de l'Alberta. Le brûlage élevée. Le nombre d'especes herbacées par quadmonent où l'humidité du sol est nomalemen ligneuses on légerement diminué augmenté. Dans les prairies et les zones arbusives forêt a diminué et celui de la prairie a occidenalis eide la graminee festuco sos arbusives, le couvent de l'arbuste symptoricarpos la plus forte augmentation sont Calanoubra lan a fortement diminué. Les espèces qui ont accusé

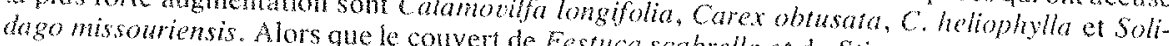
diminail, leur fréquence augmentait Le couvert de towella et de Stipa spartea var. curtiseta Populus tremuloides, a diminué, alors que laver de tous les arbustes, sauf les drageons de adaptés au feu: Elacagnus commutara, Amelanchier augmentait chez les especes suivantes, les drageons de Populus tremuloides. Le brîlanchier alnifolia, Prunus virginianta, ainsi que chez les principales Graminées et Cypéracées. L effet du but longueur du limbe foliaire chez toutes difere d'unc espece à l'autre. Le brûlage a réduit du brûlage sur la production d'inflorescences et les Cypérncées subissant une réducto a reduit la production annuelle d'herbes, les Graminées matière organique el de la teneur en phosphore de lhoriz. Il a provoqué une augmentation de la misible sul la condition de l'azote dans lborizon $A$ h.

[Traduit par le journal]

\section{Introtuction}

fire played a significan role in the aspen park gid of western Canada pror to white settement yelson and England 1971). The frequency of ming dedined following this settement. Subguently, woody vegetation has encroached into adjacent grasslands (Coupland and Maini 1959; fley and Wroe 1974; Schener 1976). The efrect angle fre on grasslands has beon reported in ny studies (Daubenmire 1968): a single fall or Fing bura in the Festuca - Stipa grassland of the

Tesent address: Forestry Technology School, Aberta set Service, Binton, Alta. central Aberta aspen parkland was repored by Bailey and Anderson (1978). There are lew studies, however, of the effect of anmual burning on grass. lands and none of the effect of annual burning on a northem prairie dominated by a cool season grass like Festrea scabrella.

This study examined the effect of ammal early spring buming on species composition and standing cop of native grassland vegetation in the aspen parkland of central Alberta.

\section{Sturly arras}

The following criteria were relied upon in sclecting a suitable study area: (i) buming must 
have been of sufficient frequency to produce an ecosystemadaped to fire; (ii) burnce and whimod areas must be in close proximity so that paired comparisons could be made on similar soils and topography; (iii) grazing, browsing, and other disturbances must have been of minor significance. The Camp Wainwright Military Reserve, approximately $192 \mathrm{~km}$ southeast of Edmonton, Alta., net these requirements. Study sites were confined to Tp. 44 R. 7 WAM (Fig. 1). Topography was undulating to gently rolling. Mean elevation was approximately $610 \mathrm{~m}$. Predominant landforms consisted of kames and kame moraines (Bayrock 1967). The orthic or rego black, or dark brown, chernozemic soils had sand or sandy loam textures (Wyatt ef al. 1944). The vegetation was a complex mosaic of groves of Populus tremuloides groves and grasslands dominated by Festuca scabrella and Stipa spartea var. curtiseta. Tree density ranged from 2500 to $15200 \mathrm{stems} / \mathrm{ha}$. Basal area in

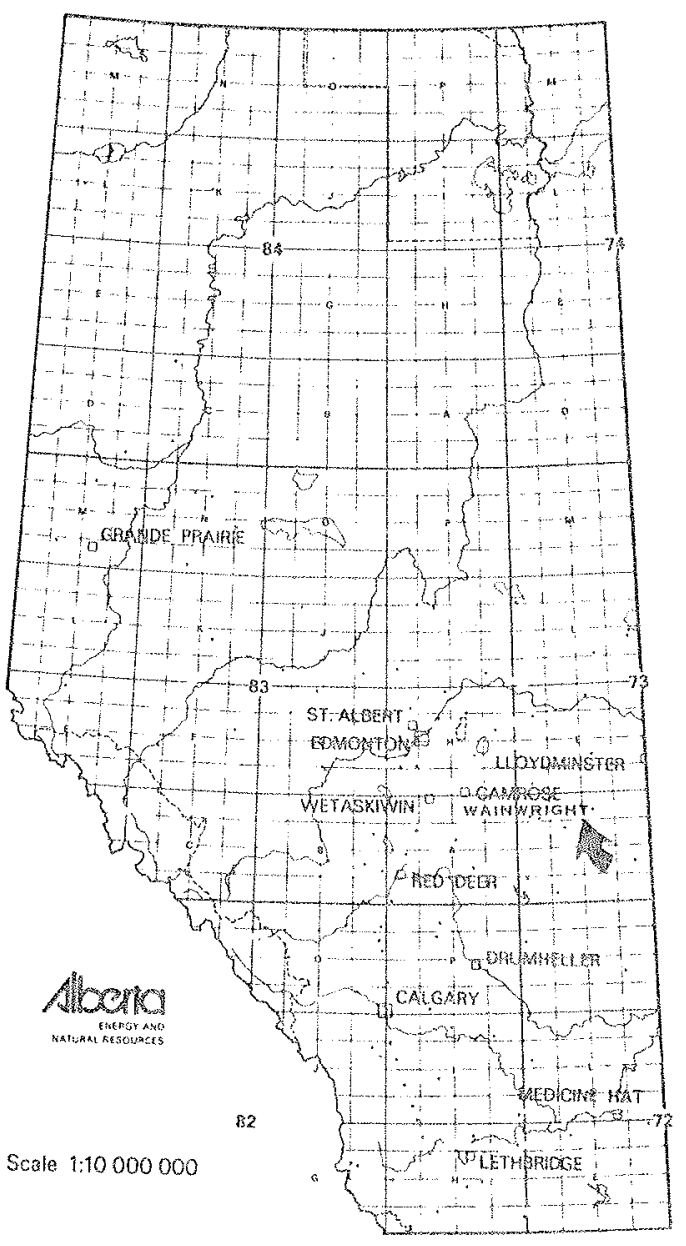

Fig. 1. Location of the study area. dense young stands was less than $0.5 \mathrm{~m}^{2} / \mathrm{h}$. whereas in onter stands it ranged from 1.7 to 2 th $\mathrm{m}^{2} / \mathrm{ha}$. Shrubs (Symphoricarpos occidentals? Wlacagnas commitata) were common in the grassland. In Saskatchewan. Coupland ant Brayshaw (1953) have described this vegetatiot mosaic. Festuca attains its optimum developmentit on lower slopes of north or east exposure (Ayya and Dix 1964: Cosby 1964 .

Annual precipitation a Fabyan, $13.5 \mathrm{~km}$ north northwest, averaged $451 \mathrm{~mm}$ with the monthly maximum of $108 \mathrm{~mm}$ occurring during June (Atme spheric Environment Service 1976). Approx mately $65 \%$ of annual precipitation occurred b. tween May 1 and September 30. Annual mean dail temperatures at Heath, $25 \mathrm{~km}$ east-northeast, aver aged $2.9^{\circ} \mathrm{C}$ with May to September (inclusive) val ues averaging $13.5^{\circ} \mathrm{C}$.

An annually burned core area of approximate 8100 ha was surrounded by unburned stands of $h$ tive vegetation. Burned and unburned areas werl separated by a road and fire guard.

\section{Methods}

Pour paits of $2 \mathrm{~m}$ wide belt transects totaling $1480 \mathrm{~m}$ in lent: were established in burned and unburned areas. The transt covered a range of topographic, edaphic, and vegetation cont tions in grassland and shrubland in each treatment. The propy tion of moist and dry sites sampled on burned and unburnt areas was approxinately equal. Transects were randomly cated within areas undisturbed by nilitary vehicles or exply sives.

Composition of grasses, sedges, forbs, and low shrth $(<0.1 \mathrm{dm}$ height $)$ was estimated in July and August 1976, usi 916 quadrats, $0.1 \mathrm{~m} \times 0.1 \mathrm{~m}$, randomly located within the 1 rot sects. Canopy cover (class midpoints $2.5,7.5,17.5,37.5,62$. 85 , and $97.5 \%$, number of inflorescences and average maximut leaf blade lengths of major grasses and sedges were recorded cach quadrat. Shrub cover and densily were recorded from 7 quadrats, $0.5 \mathrm{~m} \times 0.5 \mathrm{~m}$, randomly located within each transe 5 pecies nomenclature follows Moss (1959).

Estimates of standing crop of grass- and shrub-dominto communities were obtained from two replicate quadrats, 0.5 $\times 0.5 \mathrm{~m}$, within each transect (16 quadrats in total). Vegetatix was clipped at ground level in mid-August 1976, field sorted in components (shrub, grass, forb, litter), subsequently ove dried, and weighed.

The numient status ( $K, P, C a$ ), fibre percentage, and moistlit content of current-year grass foliage was determined in mith August on bumed and unburned areas from three sites on 1 tro transects (upper and lower slope positions on southerly ext? sures and upper slope positions on a northerly exposure).

Standard soil analyses $(K, P$, nitrate $N, N a, S$, and $p H)$ wit camied out for $A$ and $B$ horizons from two slope positions (upp and lower south exposures) on bumed and unburned transect In addition samples of the Ah horizon were collected during th 3rd week in October when nitrogen levels were stable (Eagle Mathews 1958). The Ah was separated into an upper portity (0-5 $\mathrm{cm}$ depth, less compact, and not well decomposed) and lower portion $6-15 \mathrm{~cm}$ depth, more compact, and well decor posed). Three sites were selected from each of the iwo tret mens, each site consisting of two pits with three replical 
wen from each pit. Organic matter content was determined by uss on ignition. Nitrogen supplying power of the Ah horizon was assessed by a technique similar to one described by Eagle and Mathews (1958). Half of each sample was incubated at $37^{\circ} \mathrm{C}$ for 4 weeks with moisture contents maintained at or near field apacicy. Nitrate and ammonia forms of nitrogen were determined by stean distillation (Bremmer 1965).

Statistical comparisons of bumed with unbumed areas were made by analysis of variance and Duncan s multiple range test.

\section{$\operatorname{Resution}$}

Species diversity (number of species per unit rea) generally increased with burning in grass and shribland (Table 1). Burned areas had twice as many grass and sedge species as unburned ones. The number of forb species also increased with hurning. There was a marginal decrease in the number of shrub species. Ammal carly spring furning reduced the proportion of forest and has resuled in a considerable expansion of grassland (Figs. 2 and 3). This spring burning has also checked the invasion of Populus tremuloides into grassiand (Fig. 4). Shrub height was reduced markedly.

Cover of herbaceous species frequently increased with burning of grass and shrublands while most woody species declined (Table 2). Amongst the grasses, the increasers were primanily species gdapted to the northern mixed privies. calmmoulfa longifolia, a species well adapted to gndy soils, increased gready in canopy cover and frquency. Although Bouteloua gracilis and Agnopyron smithii did not occur in unburned areas, thy were present in at least $10 \%$ of the quadrats in bumed areas. Carex obtusata and $C$. heliophila, wo early growing sedges, increased sharply under muming. Solidago missomiensis was the fort which increased the most under amual spring muning.

Under burning, decreasers in cover included dominan species of the unburned grassland. Major pecies included the grasses festuca scabrella, stipa spartea var. curtista, the sedge Carex sto cata, and the shrubs symphoncapos occidentalis, Daegonus commuata, Amelanchior almifolin, Rubus strigosus, and two species of Rosa. The only wody species that increased in cover under bum

TABLE 1 . Species diversily in unbuned and bumed areas (quadrat size: herbs $=0.1 \mathrm{~m}^{2}$, shrob $=$ $\left.0.5 \mathrm{~m}^{2}\right)(n=343-573)$

\begin{tabular}{lcc}
\hline & Unburned & Bumed \\
\hline Grasses and sedges & 2.2 & 4.6 \\
Forbs & 2.5 & 4.0 \\
Grasses, sedges, and forbs & 4.7 & 8.6 \\
Shrubs & 2.0 & 1.7 \\
\hline
\end{tabular}

ing were the suckers of Populas tomuloides and the half-shub Antmisiafigida.

Changes in frequency largely coincided with the changes in cover. There were some notable exceptions, however, among the major species. Three shrubs, Elacagnus commutata, Rosa arkansana, and Amelanchier anifolia showed a decrease in cover but an increase in frequency due to burning.

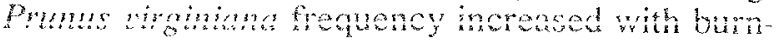
ing but cover did not change. The two dominant grasses, Festuca scabrella and Stipa spartea var. curiseta, showed an increase in frequency but a decrease in cover due to fre. Galitm boreale frequency showed no change due to fre while cover increased. Smilacina stellata frequency increased due to fre with cover showing no change.

Density of three shrubs decreased under burning, fou major shrubs increased, and four species did not change (Table 3). The highest mean stem density encountered was for Symphoricarpos occidentalis in either burned or unbumed areas.

Buming reduced blade length of major grass and sedge species (Table 4), Festuca scabrella, Sripa spartea var. curtiseta, and Agropyron subsecundum had the greatest reduction in blade length.

wo aspects of inflorescence production were affected by buming (Table 5). Percentage presence of seed heads was higher on the bumed area

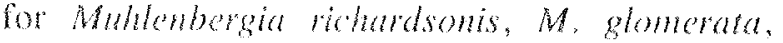
Calamovilfa Longifolia, Boutclowa gracilis, and Koelevia cristan. Seed head density was higher on the burned treatment for Muhlenbergia richardsomis, M. glomema, Canex siccana, Agrostis scabra, Bontelon gractis, and Carex obtusata. Thighesi seed head density for Stipa spantea var. cumbeta and Festuca scabrella occumed on the unbumed reatment. Flowering in Agropyron subse'chindum appeared tnaffected by buming.

Annual buning substantially reduced aboveground biomass (Table 6). Standing crop of shrubs was reduced the most but grasses and sedges were reduced by about $50 \%$. Burning kepi liter at a very low level.

In August, the nutrents $N, P, K$, and Cawere not signincantly diferent in grass and sedge foliage between bumed and unbumed areas. Crude fbre was significantly lower $(p<0.05)$ in burned areas (18.9 versus $20.5 \%)$

Soll tests revealed no difference between bumed and unbured areas for $\mathrm{N}, \mathrm{K}, \mathrm{S}, \mathrm{Na}$, and $\mathrm{pH}$. However, the number of samples was small $(n=4)$. Phosphorus was signifantly greater $(P<0.05)$ in the Ah horizon of bumed areas (11.2 versus $6.7 \mathrm{~kg} / \mathrm{ha}$.

The organic matter content of Ah horizons was 


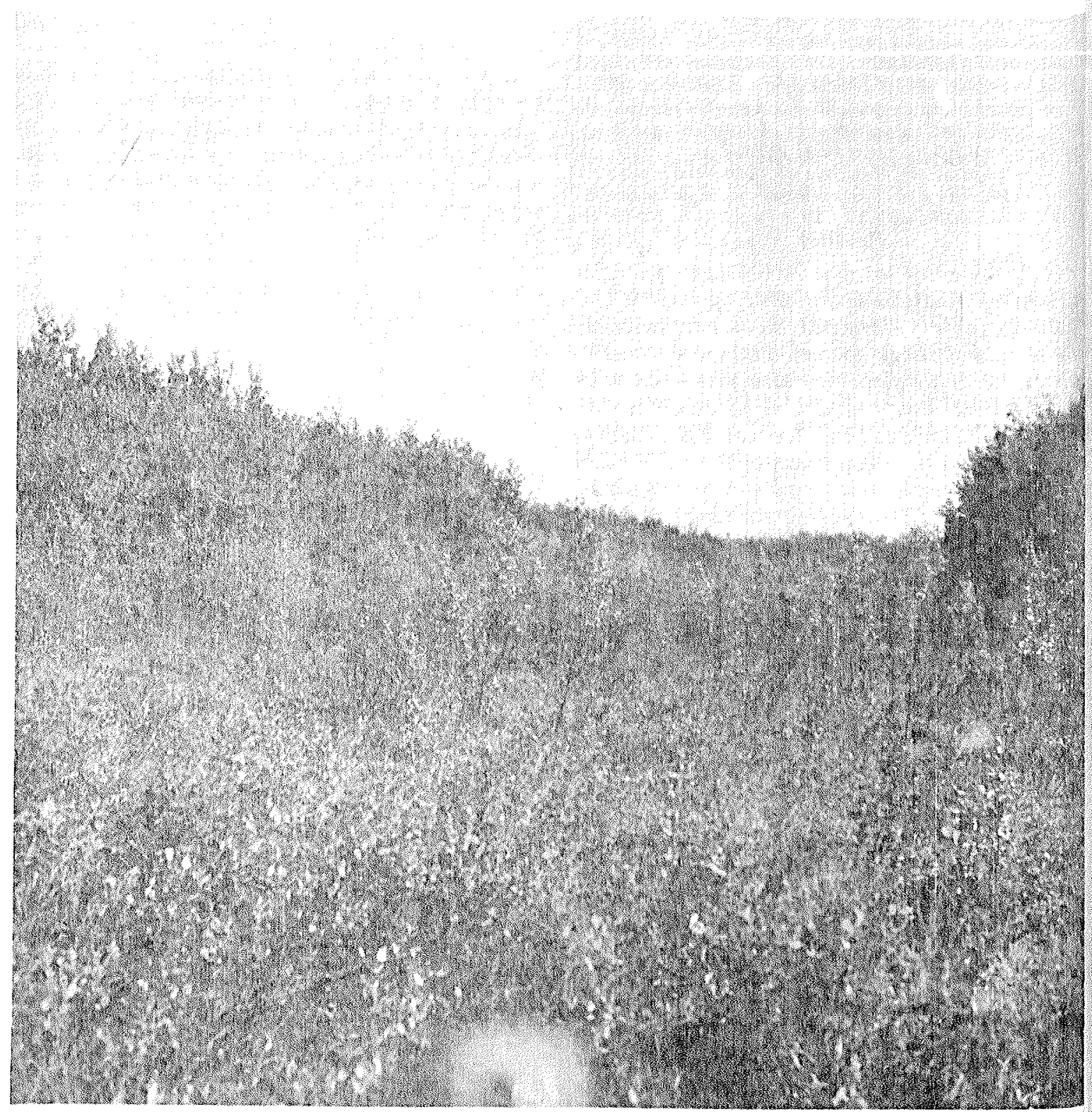

Fio, 2. Unburned vegetation with dense cover of Elaeggnus, Symphoricarpos, and Festuca between Populus groves.

greater in burned than unbumed areas (Table 7). There was little difference in bulk density between burned and unbuned areas. Under feld conditions, the dominant form of nitrogen was ammonia (Table 8). After incubation of the surface soil, however, nitrate nitrogen became the dominant form. Total nitrogen (ammonia plus nitrate) supplying power of the surface soil was not materially altered by annual burning.

\section{Disemssion}

The historical review by Nelson and England (1971) documented the high frequency of fire on
Canadian prairie grasslands prior to settlement Presettement repeated burning maintained or ex panded grassland at the expense of forest in man? areas. The present study quantifies some of these early observations. Annual early spring burning dif not eliminate any woody species since all sproutel after fire. All woody plants studied were adapted spring fire. These have developed in a grasslant where fire was one of the environmental compe nents of the ecosystem. It has been cessation of this natural environmental component that has resulte in sharp changes in the vegetation mosaic. Fire is? useful tool in maintaining grass dominance in ent 


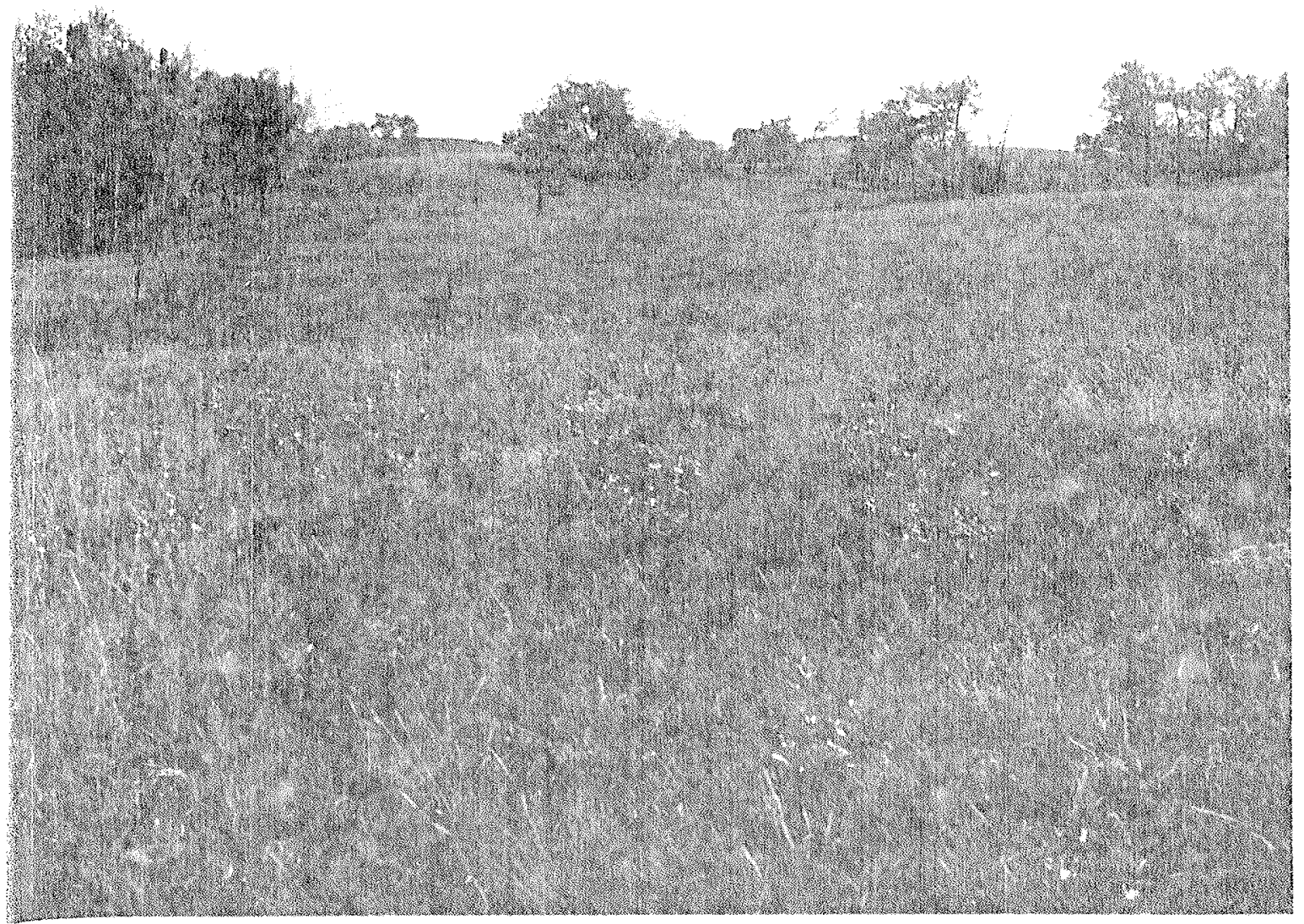

FiG. 3. Vegetation buned annualy in carly spring. Grassland has a high density of Elacagntes. Fire has not bumed through and killed trees in Populus grove on extreme left of photograph but has bumed amongst all other trees.

nments where woody species invade grasslands aubenmire 1968).

Annul buning caused an increase in the number Agrass, sedge, and forb specics. Forbs are generIly enhanced by burning (Hensel 1923; DaubenGre 1968). Annual burning prevented litter acunulation on grasslands. The more exposed soil urface in burned areas would be a more favourable cedbed than in unburned areas. Similar results vere found by Anderson and Bailey (1979) arter a ingle burn in a Symphoricarpos occidentalis mmunity. High temperatures were realized when the shrubs burned (Bailey and Anderson 1980) consuming the shrubs, creating a favourable seedbed, and reducing plant competition for seedlings. However, a single burn in adjacent grassland gave different results. Bailey and Anderson (1978) found little change in the number of species after one spring or fall burn in Festuca - Stipa grassland. It apparently requires more than one spring or fall fire to create a favourable seedbed.

In grasslands, the major decreasers in canopy cover were the shrub Symphoricapos occidenialis and the cool season grass Festuct scabrella. An- 


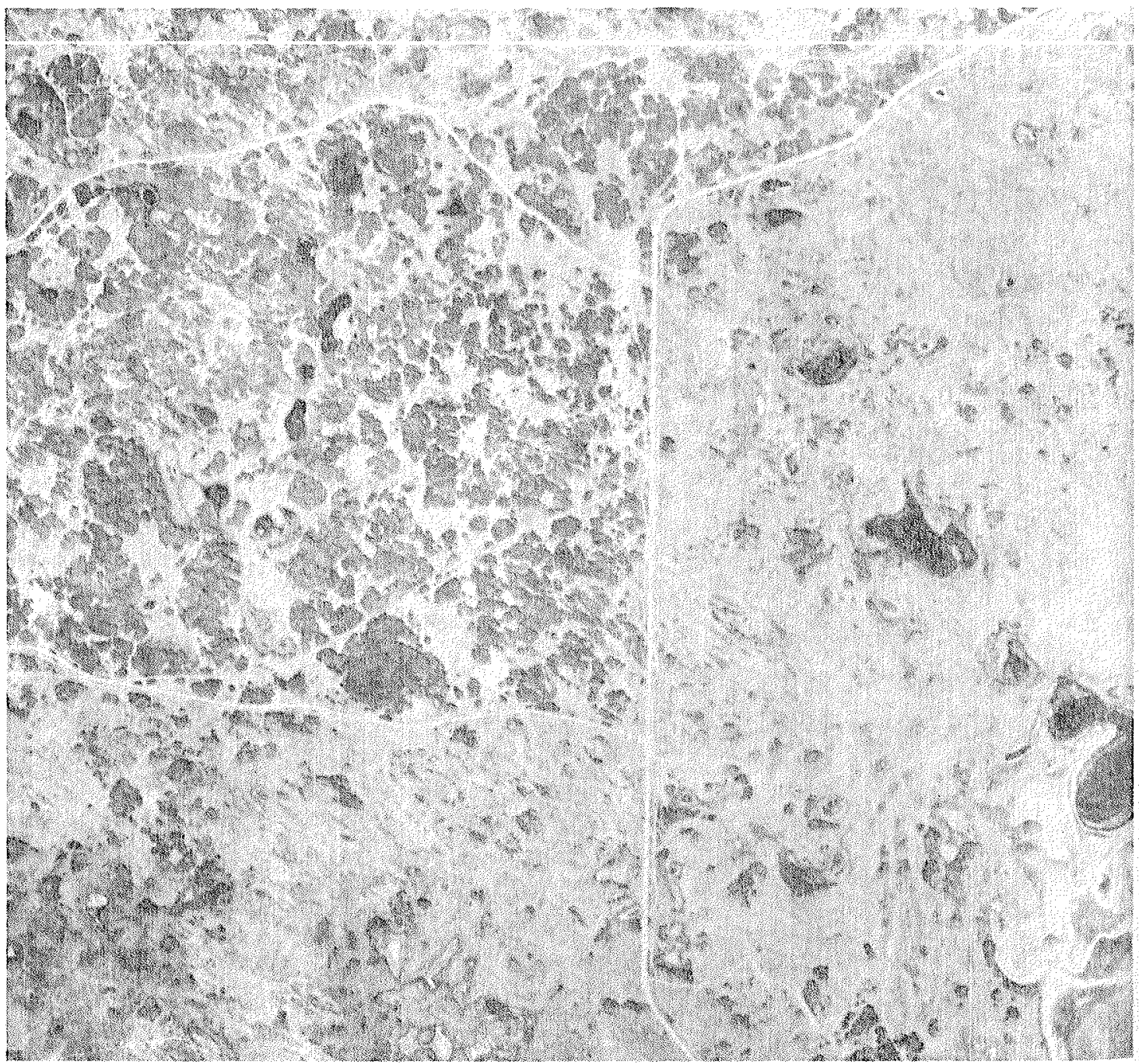

FIG. 4. Aerial photograph showing unbumed (upper left) and bumed aspen parkland vegetation (right and lower left) (Alberta Energy and Natural Resources, 1975, photo No. AS1417-165, scale 1:31680).

nual burning killed many stems of Symphoricarpos each year but the root system was not killed. In British Columbia, Mclean (1969) classified Sym. phoricarpos albus as having a root and rhizome system that made it resistant to wild fres. In Kansas, annual early spring burning reduced stem density of Symphoricarpos orbiculatus, while late spring burning eliminated the shrub (Smith and Owensby 1972).

Burning has resulted in a shift from a relatively few large plants to many small plants. The frequency increases following burning are attributable to increased resprouting by shrubs and increased tiller production in grasses. The shorter blade length of grasses in bumed areas probably accounts for the decline in canopy cover.
The deleterious effects of early spring fires cool season grasses has been reported many time (e.g., Hensel 1923; Robocker and Miller 195 Ehrenreich and Aikman 1963). Festuca scabril initiated growth early in spring. Bailey and Ander son (1978) found that a single spring burn reduce Festuca canopy cover more so than a single bl burn. They found that Festuca inflorescence pro duction was sharply reduced by a spring burn bo not affected by a fall bum. Early spring antu burning decreased Festuca cover, blade lengt and climinated seed production but its frequency occurrence increased. Fesfuca is the major of tributor to grass biomass production in unburn areas. Since tiller density and canopy height wert the primary criteria infuencing yield in Brom 
inermis (Tan ot al. 1977), it is likely that reduced canopy cover and blade length of Festuca was an important factor in the lower grass and sedge pro. duction component of standing crop in burned areas. It is evident that Festuca is well adapted to surviving annual early spring burning. Bailey and Anderson (1978) found that a single spring burs reduced Festuca canopy cover but did not reduce annual herbage production. In this study we have found that annual burning reduced Festuca canopy cover and annual herbage production. The land manager should investigate the use of periodic, rather than annual, early spring burning if maximum Festuca production is an objective.

The $50 \%$ reduction in cover of Festuca scabrella was one of the largest noted for any species. Festura also did not produce seed heads under annual spring burning. Moss (1955) noted that the botanist John Macoun failed to record Fesinca scabrella in the aspen parkland in the 1880's (Macoun 1882), although he did observe a Festuca in the Cypress Hills. The scarcity of seed heads and low canopy cover of Festuca associated with frequent fire may explain Macoun's observation. The reduction in fire frequency following settlement may have been favourable for the increased importance of Festuca scabrella during the twentieth century. Macoun (1882) considered "northern buffalo grass"' (Stipa spartea var. curtiseta) as the dominant grass of the aspen parkland region.

Annual early spring burning does favour certain wol season plants. The grasses Helictotrichon Wroker and Agropyron smithii and the sedges care obtusata and $C$. hellophylla increased in toth frequency and canopy cover. Season of frow in intiation was not the only factor infuencing flant response to burning. Grassland fires tend to reate a more arid environment because of less liter cover and lower soil moisture status (Delong and MacDonald 1975). Grasses adapted to drier nvironments are favoured over species adapted to nore mesic conditions. All grasses classified as ncreasers in Table 2 are found in the mixed prairie (Coupland 1950). Ammal early spring burning has caused a shift in grass and sedge species composiIinn away from species of the Festuca scabrella grasslands in favour of species from the mixed praire association.

The warm season mixed prairie grasses, falamovilfa longifolia, Oryzopsis hymenoides, uhlenbergia richardsonis, and Bomelout wicilis, all do well on disturbed sites and on sandy wills. They start grow th late in the spring and flower set in the season. Solidago missouriensis, the rorb wost beneficially affected by annual burning, also flowers late in the growing season. The fwo lowgrowing sedges favoured by fire start growth and fower eanly. They may have responded to a reduc. tion in competition because of reduced cover and blade length of dominant grasses; this may more than offset any deleterious effects of early spring nire.

Response of Stipa spartea var. curtiseta to fire is intermediate between the warm season mixed prairie grasses such as Calamovilfa longifolia and the cool season grasses such as Festuca scabrella or Agropyron subsecundum. This Stipa species is the codominant of the Stipa-Agropyron faciation (Coupland 1950), the most mesic community of the northem mixed prairie. Stipa starts growth later than Festuca. A single spring burn did not affect Stipa canopy cover and it stimulated inforescence production for 3 years, whereas a single fall burn reduced cover and seed heads (Bailey and Ander. son 1978). An increase in aridity should favour Stipa over Festuca. This is the case. In burned areas, the percentage reduction in canopy cover, blade length, and seed-head density was less in Stipa than in Festuca.

The effect of buming on herbage yields is variable. Hensel (1923) reported a reduction in yield of an Andropogon-Bouteloua-poa prairie while in a more mesic area, Iowa, an increase in an Andropogon-Sorghastrum praine was evident (Ehrenreich and Aikman 1963). Coupland (1973) found a reduction in herbage yields for 3 years after an Agropyron - Koeleria community was burned by August wildfire. Bailey and Anderson (1978) reported no significant change in herbage production after either a single spring or fall prescribed burn in Festuca - Stipa grassland. Annual herbage production in unburned areas of the present study was similar to those reported by Bailey (1970) and Bailey and Anderson (1978) for the Festuca-Stipa community $50 \mathrm{~km}$ northwest of the present study area. In his review, Daubenmire (1968) noted that burning of warm season grasses in mesic parts of the Great Plains caused an increase in herbage production while burning in arid parts of the Great Plains caused a decrease in herbage. In Africa, West (1965) observed that fire increased production in more moist regions but was generally detrimental in more arid regions. In Texas, Wright (1972) and Wink and Wright (1973) found that one prescribed burn during a wet year stimulated production whereas a burn during a dry year caused a further reduction in yield. In our study, annual burning favoured a species change rowards plants adapted to more arid areas. Amual herbage production probably declined mainly as a result of a decline in 
TABLE 2. Frequency and canopy cover of common spoces on bumed and unburned grass and shrublands

\begin{tabular}{|c|c|c|c|c|}
\hline \multirow[b]{2}{*}{ Species* } & \multicolumn{2}{|c|}{ Erequency, $\%$} & \multicolumn{2}{|c|}{ Canopy cover $\%$} \\
\hline & $\begin{array}{l}\text { Unburned } \\
(n=458)\end{array}$ & $\begin{array}{c}\text { Bumed } \\
(n=458)\end{array}$ & $\begin{array}{l}\text { Unburned } \\
(n-458)\end{array}$ & $\begin{array}{c}\text { Burned } \\
(n=458)\end{array}$ \\
\hline Grasses & & & & \\
\hline 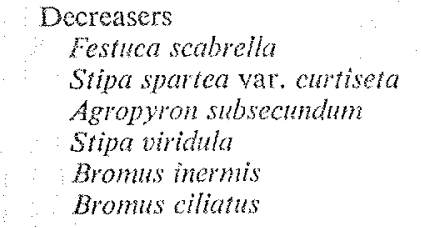 & $\begin{array}{r}65 \\
45 \\
30 \\
6 \\
5 \\
4\end{array}$ & $\begin{array}{r}82 \\
68 \\
20 \\
0 \\
2 \\
1\end{array}$ & $\begin{array}{c}36 a \\
15 c \\
3 a \\
1.6 a \\
1.2 c \\
0.30\end{array}$ & $\begin{array}{l}18 b \\
11 a \\
1.2 b \\
0 b \\
0.2 a \\
+a\end{array}$ \\
\hline 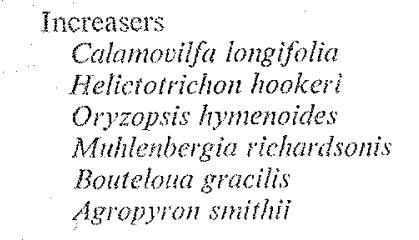 & $\begin{array}{l}3 \\
2 \\
3 \\
2 \\
0 \\
0\end{array}$ & $\begin{array}{l}49 \\
48 \\
16 \\
4 \\
13 \\
10\end{array}$ & $\begin{array}{l}0.7 b \\
0.1 b \\
0.1 b \\
0.9 d \\
0 b \\
0 b\end{array}$ & $\begin{array}{l}41 a \\
2 a \\
0.6 a \\
1.3 c \\
1.3 a \\
0.5 a\end{array}$ \\
\hline $\begin{array}{l}\text { Sedges and rushes } \\
\text { Decreasers } \\
\text { Carex siccata } \\
\text { Carex deffexa } \\
\text { Carex spp. } \\
\text { Carex dolglasii }\end{array}$ & $\begin{array}{r}14 \\
6 \\
3 \\
4\end{array}$ & $\begin{array}{l}3 \\
0 \\
0 \\
0\end{array}$ & $\begin{array}{l}40 \\
1.10 \\
0.9 c \\
0.7 c\end{array}$ & $\begin{array}{l}0.5 b \\
0 b \\
0 d \\
0 d\end{array}$ \\
\hline $\begin{array}{l}\text { Increasers } \\
\text { Carex obuasata } \\
\text { Carex heliophila }\end{array}$ & $\begin{array}{l}10 \\
+\end{array}$ & $\begin{array}{l}91 \\
26\end{array}$ & $\begin{array}{l}1.16 \\
+b \dagger\end{array}$ & $\begin{array}{l}18 a \\
14 a\end{array}$ \\
\hline $\begin{array}{l}\text { No change } \\
\text { Cares perki } \\
\text { Juthen boltious }\end{array}$ & $\begin{array}{l}2 \\
3\end{array}$ & $\begin{array}{l}1 \\
3\end{array}$ & $\begin{array}{l}0.5 n \\
0.2 a\end{array}$ & $\begin{array}{l}0.1 a \\
0.1 a\end{array}$ \\
\hline 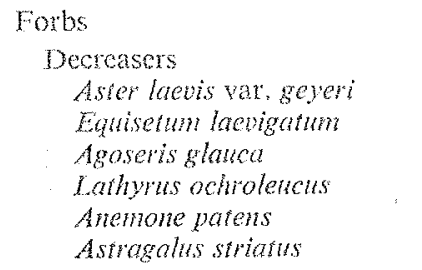 & $\begin{array}{r}9 \\
15 \\
5 \\
3 \\
2 \\
5\end{array}$ & $\begin{array}{r}6 \\
8 \\
2 \\
+ \\
5 \\
2\end{array}$ & $\begin{array}{l}1.2 e \\
0.5 e \\
0.6 a \\
0.2 a \\
0.1 a \\
0.2 e\end{array}$ & $\begin{array}{l}0.5 f \\
0.3 f \\
0.1 b \\
+b \\
+b \\
0.1 f\end{array}$ \\
\hline 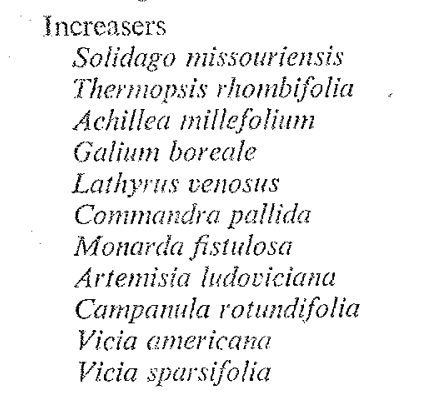 & $\begin{array}{r}18 \\
14 \\
23 \\
22 \\
2 \\
9 \\
5 \\
24 \\
17 \\
4 \\
4\end{array}$ & $\begin{array}{r}50 \\
47 \\
36 \\
20 \\
15 \\
37 \\
9 \\
31 \\
24 \\
10 \\
8\end{array}$ & $\begin{array}{l}1.7 b \\
0.7 b \\
1.1 b \\
1.0 b \\
0.1 b \\
0.3 b \\
0.5 f \\
2 b \\
0.5 f \\
0.2 b \\
0.1 f\end{array}$ & $\begin{array}{l}27 a \\
3 a \\
3 a \\
4 a \\
1.2 a \\
2 a \\
1.3 e \\
3 a \\
0.9 e \\
0.5 a \\
0.3 e\end{array}$ \\
\hline 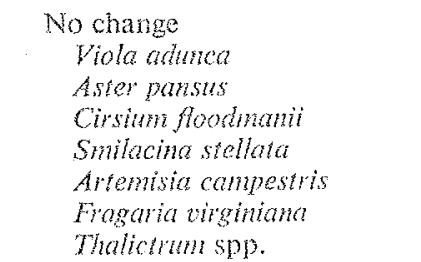 & $\begin{array}{l}5 \\
4 \\
2 \\
4 \\
1 \\
2 \\
2\end{array}$ & $\begin{array}{l}6 \\
6 \\
1 \\
7 \\
3 \\
4 \\
4\end{array}$ & $\begin{array}{l}0.3 a \\
0.4 a \\
0.4 a \\
0.3 a \\
0.3 a \\
0.1 a \\
0.1 a\end{array}$ & $\begin{array}{l}0.5 a \\
1.0 a \\
0.1 a \\
0.3 a \\
0.2 a \\
0.2 a \\
0.1 a\end{array}$ \\
\hline
\end{tabular}


Table 2. (Conchuled)

\begin{tabular}{|c|c|c|c|c|}
\hline \multirow[b]{2}{*}{ Species* } & \multicolumn{2}{|c|}{ Frequency, $\%$} & \multicolumn{2}{|c|}{ Canony cover, \% } \\
\hline & $\begin{array}{l}\text { Unbumed } \\
(n=458)\end{array}$ & $\begin{array}{c}\text { Bumed } \\
(n=458)\end{array}$ & $\begin{array}{l}\text { Unburned } \\
(n=458)\end{array}$ & $\begin{array}{c}\text { Burned } \\
(h t=-=458)\end{array}$ \\
\hline \multicolumn{5}{|l|}{ Shrubs } \\
\hline \multicolumn{5}{|l|}{ Decreasers } \\
\hline Symphoricapos occhentals & 56 & 52 & $31 a$ & $2 b$ \\
\hline Elaeagnus commurara & 20 & 34 & $4 a$ & $2 b$ \\
\hline Anelanchier alnifolia & 8 & 16 & ala & $1.4 b$ \\
\hline Rosa acicularis & 13 & 1 & $3 a$ & $0.4 b$ \\
\hline Rubus strigasts.s & 5 & 2 & $1.2 a$ & 0.16 \\
\hline Rosa arkanswna & 11 & 24 & $1.3 e$ & $0.6 f$ \\
\hline \multicolumn{5}{|l|}{ Increasers } \\
\hline Populus tremmoides (suckers) & 3 & 18 & $0.2 b \gamma$ & $0.9 a$ \\
\hline Artemisiafrigida & 3 & 7 & $0.2 f$ & $0.3 m^{*}$ \\
\hline \multicolumn{5}{|l|}{ No change } \\
\hline Pranes virginiano & 6 & 15 & $1.9 a$ & $1.5 a$ \\
\hline Pruntus pensylbantica & 2 & 2 & $0.4 a$ & $0.1 a$ \\
\hline
\end{tabular}

(18u 3 . Effect of annual burning on shrub density number per square metre)

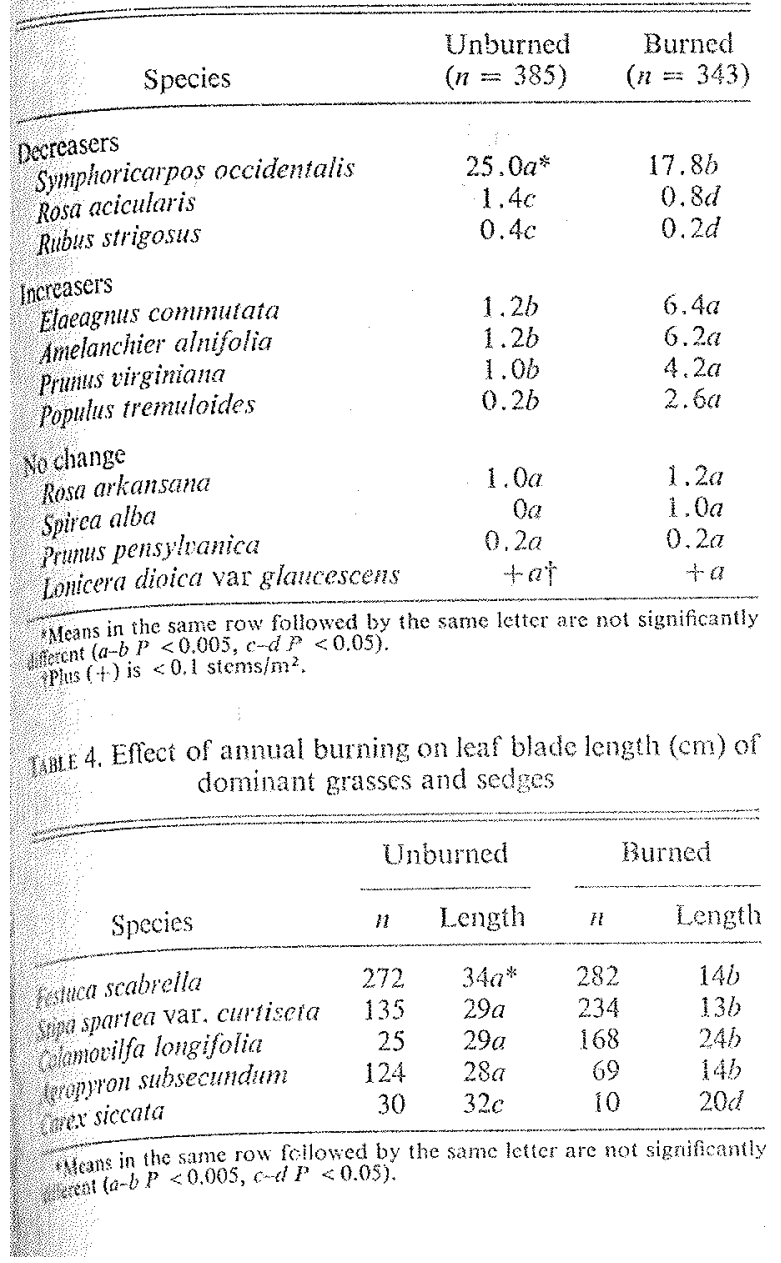

blade length and cover of the dominant perennial grasses, Festuca scabrella and Stipa spartea var. curtiseta. The decline in blade length and canopy cover of Festma and Stipa is probably closely related to the more arid microclimate caused by spring burning. Lower soil moisture levels on burned areas as compared with unbumed areas were atributed to reduced infiltration rate and a reduction in soil moisture recharge during the winter period due to a loss of snow (DeJong and MacDonald 1975). There is probably a greater evaporation loss because of the absence of litter. These factors have a detrimental effect on the plant water status (Redmann 1978). He concluded that greate: water stress in plants growing on an October bumed site on a clay soil in the arid mixed prairic could explain the reductions in primary prodrction. In this grassland at the northern extremes of the Great Plains, factors in addition to aridicy are responsible for the decline of productivity under burning. Season of burning is very important and is poorly understood. It is known, however that spring burning does detrimentally affect the cool season grass dominant, Festuca seabrella (Bailey and Anderson 1978).

Changes in shrub density largely reflect resprouting capacity and adaptation of each species to the new microclimate. Those shrubs showing increased density after burning have a high capacity to regenerate from suckers and can survive under the more arid conditions while those showing a decrease have a lower ability.

Elacagnus commutata is a nitrogen-fixer (Vlas- 
Wabe. 5. Ffect of annul burning on inforescence production of common grasses and sedges

\begin{tabular}{|c|c|c|c|c|c|c|}
\hline \multirow[b]{2}{*}{ Species } & \multicolumn{3}{|c|}{ Unburned } & \multicolumn{3}{|c|}{ Bumed } \\
\hline & $n^{*}$ & $\begin{array}{c}\text { Presence, } \\
\%\end{array}$ & $\begin{array}{l}\text { Density, } \\
\text { no. } / \mathrm{m}^{2}\end{array}$ & $n$ & $\begin{array}{c}\text { Presence, } \\
\%\end{array}$ & $\begin{array}{c}\text { Density, } \\
\text { no. } / \mathrm{m}^{2}\end{array}$ \\
\hline Muhlonbergia vichardsonis & 3 & 33 & 130 & 13 & 100 & 483 \\
\hline Carex siccata & 1 & 3 & 10 & f & 10 & 150 \\
\hline Agrostis scabra & 2 & 22 & 10 & 1 & 20 & 110 \\
\hline Calanovilfa longifolia & 6 & 24 & 13 & 67 & 40 & 18 \\
\hline Bontelona gracilis & 0 & 0 & 0 & 25 & 56 & 44 \\
\hline Muhlenbergia glomerata & 0 & 0 & 0 & 3 & 100 & 30 \\
\hline Corex obtusata & 0 & 0 & 0 & 10 & 3 & 24 \\
\hline Agropyron subsecundum & 28 & 23 & 14 & 17 & 25 & 15 \\
\hline Koeleria cristata & 4 & 36 & $17 a t$ & 8 & 73 & $14 b$ \\
\hline Poa interior & 2 & 67 & 20 & 2 & 18 & 15 \\
\hline Stipa spartea var. curiseta & 43 & 32 & $23 a$ & 45 & 19 & $14 b$ \\
\hline Festuca scabrella & 18 & 7 & 34 & 0 & 0 & 0 \\
\hline
\end{tabular}

*Number of quadrats in which seed heads were present.

* Number of quadrats in which seed heads were present.

species was found.
4 Mean for tensity within a row followed by a different letter are significanly different at $P<0.05$. Ail onher means for clensity are not signifaratiy different at $p<0.05$.

TABLE 6. Components of aboveground biomass (kg/ha) for burned and unbumed vegefation, August 1976 (oven-dry weights)

\begin{tabular}{|c|c|c|c|c|}
\hline \multirow[b]{2}{*}{ Component } & \multicolumn{2}{|c|}{ Unbumed } & \multicolumn{2}{|c|}{ Burned } \\
\hline & $\begin{array}{l}\vec{x} \pm S E \\
(n=8)\end{array}$ & $\begin{array}{c}\% \% \text { of } \\
\text { total living }\end{array}$ & $\begin{array}{l}x+9 \mathrm{C} \\
(n=8)\end{array}$ & $\begin{array}{c}\% \text { of } \\
\text { total living }\end{array}$ \\
\hline Shrub & $3217 a^{2} \pm 1609$ & 67 & $1730+171$ & 15 \\
\hline Grass and sedge & $1408 a+181$ & 30 & $7196 \pm 96$ & 60 \\
\hline Forb & $117 a \pm 40$ & 3 & $295 a \pm 64$ & 25 \\
\hline Total living & 4742 & & 1187 & \\
\hline biter & $4502 a+327$ & & $2620+235$ & \\
\hline
\end{tabular}

* Mean rabes in same row followed by the sane leter are not significantly differen $(P<0,005)$.

TABLE 7. Organic mater content $(\%)$ of soil Ah horizons $(n=-3-27)$

\begin{tabular}{|c|c|c|}
\hline $\begin{array}{l}\text { Soil depth, } \\
\mathrm{cm}\end{array}$ & $\begin{array}{c}\text { Unburned, } \\
\bar{x} \pm S E\end{array}$ & $\begin{array}{l}\text { Bumed, } \\
\bar{x} \pm S E\end{array}$ \\
\hline $0-5$ & $10.4 b^{2}+0.59$ & $14.700+1.10$ \\
\hline $6-15$ & $5.836 \pm 0.21$ & $8.30 a+0.37$ \\
\hline
\end{tabular}

sak et at. 1973) that can contribute significant quantities of nitrogen to the cosystem (Whysong and Bailey 1975), Elueagnus can tolerate nore anid conditions than found on the study area since it is common in parts of the mixed praine (Coupland 1950). Amelanchier alnifolia and Rosa arkansana also occur in more ard areas. However, Rosa acicularis and Rubus strigosus are more commonly found growing in the shade of Populus tremuloides groves rather than in the grasslands of the mixed prairie.

Numerous studies have linked fire with loss of organic matter and soil nitrogen (e.g. Isaac a Hopkins 1937; Youngberg 1953; Austin Baisinger 1955; Dymess and Youngberg 195 This may be the norm after summer forest firesh may not apply in grassland regions. In his revie Daubenmire (1968) cited several studies fronl coastal plain of the southeastern United Stat which indicated increased organic matter conte following prescribed burning. There was a trend organic matter to increase under prescribed but ing in more moist areas but to decrease in more af areas. Season of prescribed burning and soil mols ture status also affects subsequent soil organ matter levels. In Kansas, Owensby and Wyh (1973) found that under moist soil conditions winter on early spring burning, soil organic matt levels were higher than under unbumed or spring burned areas. Early spring annual burning our study resulted in an increase in soll orgal mater levels in both the $0-5$ and $6-15 \mathrm{~cm}$ depthis the Ah horizon. The increase in organic matter the Ab horizon may be related to a shift in roolit 
TABLE 8. Nitrogen status and nitrogen supplying power (ppm) of Ah horizons of grassland soils

\begin{tabular}{|c|c|c|c|c|c|c|c|c|c|c|c|c|}
\hline \multirow[b]{3}{*}{$\begin{array}{l}\text { sol } \\
\text { lepth, } \\
\text { crit }\end{array}$} & \multicolumn{6}{|c|}{ Unburned $(n=2)$} & \multicolumn{6}{|c|}{ Burned $(n=3)$} \\
\hline & \multicolumn{3}{|c|}{ Preincubation level } & \multicolumn{3}{|c|}{ Postincubation level } & \multicolumn{3}{|c|}{ Preincubation level } & \multicolumn{3}{|c|}{ Postincubation level } \\
\hline & $\mathrm{NH}^{-\mathrm{N}}$ & Non & $\begin{array}{l}\text { Anmonia } \\
\text { f nitraic }\end{array}$ & $\mathrm{XII}^{4+5}$ & $\mathrm{~N}^{1} \mathrm{O}^{3 \times 1}$ & $\begin{array}{c}\text { Ammonia } \\
\text { intmate }\end{array}$ & $\mathrm{NH}^{4+N}$ & $N O^{3} \mathrm{~N}$ & $\begin{array}{c}\text { Ammonia } \\
\text { t. nimate }\end{array}$ & $\mathrm{NH}^{4+N}$ & $\mathrm{NO}^{3} \mathrm{~N}$ & $\begin{array}{l}\text { Ammonia } \\
\text { t nitrate }\end{array}$ \\
\hline $0-5$ & $\begin{array}{l}21 \\
14\end{array}$ & $\begin{array}{l}4.5 \\
2.2\end{array}$ & 25 & $\begin{array}{l}36^{*} \\
13\end{array}$ & $\begin{array}{l}94 \phi \\
30\end{array}$ & $\begin{array}{r}130 \\
43\end{array}$ & $\begin{array}{l}18 \\
19\end{array}$ & $\begin{array}{l}6.0 \\
2.5\end{array}$ & $\begin{array}{l}24 \\
21\end{array}$ & $\begin{array}{l}10^{*} \\
33\end{array}$ & $\begin{array}{c}185 \dagger \\
29\end{array}$ & $\begin{array}{r}195 \\
62\end{array}$ \\
\hline
\end{tabular}

Tignificantly different at $P<0.05$.

significantly different at $P<0.005$.

depth. Smoliak ef al. (1972) found a shift in root concentration towards the soil surface under heavy azing of a Stipa - Bouteloua-Agropyron comnunity of the mixed prairie. Sharrow and Wright (1977) indicated that the higher levels of organic matter in Ah horizons of burned sites resulted from higher soil temperature largely due to litter removal. Dead vegetation and roots would decomtose more readily.

Nitrogen and sulfur can be volatilized during combustion; the other elements are released and re not directly lost from the ecosystem (Daubennire 1968). We found only phosphorus higher in the Shlorizon under burning. Ehrenreich and Aikman (1963) indicated that available $P$ was higher in soil in burned areas largely because of the destruction forganic matter by fire. This was probably not the ase in our study where burning was conducted soon after snowmelt when soils were moist. More available $\mathrm{P}$ is likely caused by a more rapid turnver rate of organic matter due to the higher soil temperatures.

Burning apparently increases the nitrogen supdying power of the Ah horizon but does not adwersely affect the nitrogen status of the soil. Other sudies support this conclusion (Norman and Wetstlaar 1960; Ehrenreich and Aikman 1963; Daubenmire 1968). Owensby and Wyrill (1973) lemonsirated that nitrogen levels of plots burned in ally spring were not different from unburned conrols. Sharrow and Wright (1977) found that burning did not affect total $N$ in the upper $2.5 \mathrm{~cm}$ depth sut lowered total $\mathrm{N}$ levels in the $2.5-12.5 \mathrm{~cm}$ depth merval. Nitrogen is added to the upper soil from the charred material and the nutrients from the ash flong with the warmer soil temperatures which vimulate some nitrogen depletion from lower layers by active organic decay.

Buned samples had a higher net mineralization ate of nitrogen (rate of ammonification less that of ssimilation by microorganisms) in the laboratory than unburned samples. It is uncertain whether this thenomenon will occur under ficld conditions. This response may result from narrower $\mathrm{C}: \mathrm{N}$ ratio in the organic material on burned areas.

\section{Acknowledgments}

A National Research Council of Canada operating grant to $\mathrm{A}$. W. Bailey partially supported this research. The cooperation of Camp Wainwright personnel is most appreciated. Special thanks are due to Sgt. Johnson who conscientiously ensured that the investigators could work in safety.

ATMOSPHERIC ENvironment SERvice. 1976. Monthly records, meterological observations in Canada. Environment Canada, Downsview, Ontario.

Anderson. M. L., and A. W. BAILEY. 1979. Effect of fire on a Symphoricarpos occidentalis shrub community in central Alherta. Can. J. Bot. 57: $2819-2823$.

AustiN, R. C., and D. H. BAISINGER. 1955. Some effects of burning on forest soils of western Oregon and Washington. $J$. For. $53: 275,280$.

AYYAD, M. A. G., and R. L. Dix, 1964. An analysis of a vegetation-microenvironmental complex on prairie slopes in Saskatchewan. Ecol. Monogr, 34(4): $421-442$.

BAILEY, A. W. 1970. Barrier effect of the shrub Elaeagnth commutata on grazing cattic and forage production in central Alberta. J. Range Manage. 23(4): 248-251.

BAllEY, A. W., and M. L. ANDERSON. 1978. Prescribed burning of a Festuca - Stipa grassland. J. Range Manage. 31(6): $446-449$.

- 1980 . Fire remperatures in grass, shrub and aspen forest communities in central Alberta. J. Range Manage. 33(1): $37-40$.

BAILY, A. W., and R. W. Wroe. 1974. Aspen invasion in a portion of the Alberta Parklands. J. Range Manage. 2\%(4): $263-266$.

BAYROCK. L. A. 1967. Surficial geology of the Wainwright area (cast half), Alberta. Research Council of Alberta, Edmonton, Alta. Rep. 67-4.

Bremmer, J. M. 1965. Inorganic forms of nitrogen. In Methods of soil analysis. Pt. 2. Chemical and microbiological properties. Edited by C. A. Black. Am. Soc. Agron. Madison, WI. Monogr. No.9. pp. 1179-1237.

Cosar, H. E. 1964. Some yield chancteristics of range as influenced by soil type and weather. J. Range Manage. 17: 266-269.

COUPLAND, R. T. 1950. Ecology of the mixed prairie in Canada. Ecol. Monogr. 20: 271-315.

1973. Producers: I Dynamics of aboveground standing crop. Matador Proj., Can. Ini. Biol. Program. Saskatoon, Sask. Tech. Rep. No. 27. 
Coupland, R. T., and T. C. Brayshaw. 1953, The fescine grassland in Saskatchewan. Ecology, $3 / 2(2): 386-405$.

COUPLAND, R. T, and J. S. MAIN 1959 . Wnodland invasion of westem Canadian grasslands. IX Int. Bot. Congr. Proc. II. IIA, Montreal, P.Q.

DAUDEMMIRE. R. 1968. Ecology of fire in grasstands. In Advances in ecological research. Vol. 5. Edited by J. B. Cragg.
pp. 209-266.

DIJONG, E., and K. B. MaCDONALD. 1975. The soll moisture regime under native grassland. Geoderma, 14: 207-221.

DyrNess, C. T., and C. T. Younciberg. 1957. The effect of logging and slash burning on soil structure. Soil Sci. Soc. Am. Proc. 21: 444 447 .

EAGle, D. J., and B. C. Mathews. 1958. Measmement of nitrate-supplying power of soils by an incubation method and correlation with crop yield response. Can. J. Soil Sci. $38(2)$ $161-170$.

Emrenieich, J. H., and J. M. Aikman. 1963. An ecological study of the effect of certain management practices on native prairie in Iowa. Ecol. Monogr. 33(2):113-130.

HENSEL, R. L. 1923. Effect of burning on vegetation in Kansas pastures. J. Agric. Res. 23(8): 631-643.

ISAAC, L. A., and H. G. HOPKINS, 1937. Forest soil of the Douglas fur region, and changes wrought upon it by logging and slash burning. Ecology, 18: 277-278.

Macoun, J. 1882. Manitoba and the Great North-West. World Publishing Co., Guelph, Ont.

MCLEAN, A. 1969. Fire resistance of forest species as infuenced by root systems. J. Range Manage. 22(2): 120-122. Moss, E. H. 1955. The vegetation of Aberta. Bot. Rev. 21(9):
493-567.

1959. Flora of Alberta. University of Torono Press, Toronto, Ont.

NELSON, J. G., and R. E. ENGLAND. 1971. Some comments on the causes and effects of fire in the northerngrasslands areat of Canada and the nearby United States. CA. 1750-1900. Can. Geogr. 15(4): 295-306.

NORMAN, M.J. T., and R. WETSELAAR, 1960. Losses of nitro. gen on burning native pasture at Katherine, N.T. J. Aast. Inst. Agric. Sci. 26(3): 272-273.

OWENSBY, C. E., and J. B. WrRILL, HI. 1973. Effects of range burning on Kansas Fint Hills soil. J. Range Manage. 26(3):
185-188.
REDMANN, R. E. 1978. Plant and soil water potentials followits fre in a nothern mixed grassland. J. Range Manage. 310 $443-445$.

Robooker, C. W., and B. J. Multek. 1955, effects of clipint burning, and competition on establishnent and survival some native grasses in Wisconsin. J. Range Manage. 80 $117-121$.

SCHFFFer, E. J. 1976. Aspen fores vegetation in a potton the east-central Aberta pullands. M.Sc. thesis, Univerti of Alberta. Edmonton, Alta.

SHAREOW, S. H., and H. A. Whatit, 1977. Effect of fre, ast and litter on sull nitrate, temperature, moisture and Tobos grass production in the roling plains. J. Range Manage. 394 266-270.

SMTH, E. F., and C. E. OWENBSY. 1972, Effects of fire on thi prairie grasskands. Tall Timbers Fire Ecol. Conf. Proc. t? $9-22$.

SMOLAA, S, J. F. DORMAar, and A. JOHNSTON, 1972. Lom term grazing effects on Stipa - Bouleloua prairie solls Range Manage. 25: 245-250.

TAN, W. K., G. Y. TAN, and P. D. WALTOM. 1977. Canop characters and their relationship to spring productivity Bronus inermis Leyss, Crop Sci. 17: 7-10.

VLASSAK, K., E. A. PAUL, and R. E. HARRIS. 1973. Assessmet of biological nitrogen fixation in grassland and associati sites. Plant Soil, 38: 637-649.

WEST, 0.1965. Fire in vegetation and its use in pasture mat agement, with special reference to tropical and subtroftot Africa. Commonwealth Bureau of Pasures and Crops, Con monw. Agric. Bur, Farnham Royal, Bucks, England.

Wrysong, G. L, and A. W. BaIlex. 1975. Production at nirrogen content of herbage in a silverberry (Elacagnus tom matata) community compared to adjacent grassland ar forest communities. Can. J. Plant Sci 55: 801 1 808.

WINE, R. L., and H. A. WRIGHT. 1973. Effects of fire on an aste juniper community, I. Range Manage. 26(5): 326-329.

Wrunt, H. A. 1972 . Fire as a tool to manage tobosa grassland. Tall Timbers Fire Ecol, Conf Proc. 12: 152-167.

WYAT, E. A., W, D. NEWTON, W. E. BOWSER, and 1 ODYNSKY, 1944. Soll survey of Wainwright and Vermillo sheets. University of Albera Bull. No. 42

YOUNGEERG, C. T. 1953. Slash burning and soil organic matt maintenance. J. For. 51: 202-203. 